Brit. J. industr. Med., 1962, 19, 116.

\title{
SICKNESS ABSENCE IN THE THREE PRINCIPAL ETHNIC DIVISIONS OF SINGAPORE
}

\author{
BY \\ C. P. COLLINS \\ Surgeon Captain, R.N.
}

(RECEIVED FOR PUBLICATION JULY 10, 1961)

Records of sickness for all industrial employees of H.M. Dockyard, Singapore were analysed over a calendar year, 1955-56, with a view to producing a standard rate for sickness absence in the three main ethnic divisions of this area, with particular reference to age.

Other factors, such as form or grade of employment and residence, were considered in order to test their effect, if any, upon sickness absence. The principal diagnostic groups were separated to give a general picture of the trends of sickness.

The reactions of Chinese, Indians, and Malays to disease or to any of the associated factors were found to be totally dissimilar, and the possibility of this being due to chance is so slight as to be negligible.

Comparisons are subsequently made with the one rather scanty record of another organization in South East Asia, and with detailed modern analyses of sickness absence in England. Again it is found that absence rates for inceptions per 1,000 workers and days lost per worker differ entirely both as regards the total and individual disease groups and also in the effect of age. It is evident that the ethnic grouping of the population concerned must be taken into consideration in studies of sickness absence.

During the period of one calendar year, all certificated sickness absences of male industrial workers of H.M. Dockyard, Singapore were recorded and analysed. The intention was to compare the levels of sickness among the three principal ethnic groups of employees, i.e. Chinese, Indian, and Malay.

Hitherto no examination of varying racial susceptibility to different disease groups had been attempted, and it was decided that analysis on these lines and also by age groups should be included.

\section{Method}

In H.M. Dockyard, Singapore each department had its own record books in which every employee was listed under his yard number, and his sickness absences were entered against his name. These circumstances, supported in all cases of sickness by a medical certificate, decided the basis of the survey, while the duration of the "leave" year determined the period over which it should extend.

Accordingly, commencing on March 1, 1955, the cards of every employee were collected monthly for a full year and the particulars recorded on specially prepared forms.
These included the number of absences due to sickness (inceptions) and the actual period away sick. Owing to the local habit of dividing the eight-hour day into two more or less equal shifts by the lunch break, and the fact that individuals might only present themselves for work on one shift in a day, while Saturday only held the one shift, the shift itself appeared to be the most suitable unit of absence. Thus a full week's work would consist of five days of two shifts each and one of the one only, giving a total of 11 shifts.

Hence the measures of sickness absence found are recorded as:

(a) The number of inceptions (spells) per 1,000 workers in the year.

(b) The number of shifts lost per worker in the year.

Average numbers of those employed during the year were obtained by adding the figures for those employed on March 1 and on the first of each subsequent month until the succeeding March and dividing by thirteen. The average number employed during the year thus amounted to a total of 8,078 , comprising 2,465 Chinese, 4,213 Indians, and 1,400 Malays. 
TABLE 1

THE MALE INDUSTRIAL POPULATION OF H.M. DOCKYARD, SINGAPORE, 1955-56, IN AGE GROUPS AMONG THE THREE PRINCIPAL ETHNIC DIVISIONS

\begin{tabular}{c|c|c|c|c|c|c}
\hline \multirow{2}{*}{$\begin{array}{c}\text { Age } \\
\text { (years) }\end{array}$} & \multicolumn{2}{|c|}{ Chinese } & \multicolumn{2}{|c|}{ Indian } & \multicolumn{2}{|c}{ Malay } \\
\cline { 2 - 7 } & No. & Per Cent. & No. & Per Cent. & No. & Per Cent. \\
\hline $16-$ & 737 & 29.9 & 649 & 15.4 & 395 & 28.2 \\
$26-$ & 653 & 26.5 & 1,367 & 32.4 & 492 & 35.1 \\
$36-$ & 457 & 18.5 & 1,456 & 34.6 & 292 & 20.9 \\
$46-$ & 402 & 16.3 & 595 & 14.1 & 173 & 12.4 \\
$56+$ & 216 & 8.8 & 146 & 3.5 & 48 & 3.4 \\
\hline Total & 2,465 & 100.0 & 4,213 & $100 \cdot 0$ & 1,400 & $100 \cdot 0$ \\
\hline
\end{tabular}

But during the year 355 men were discharged from the Dockyard Service for a variety of reasons ranging from death and medical unfitness to old age, as disciplinary measures, or at their own request. In the same period 260 men were entered on the books. To obtain the correct average for the year, individual cards were discarded meticulously from the first half of those discharged and the last half of those entered until the calculated figure had been reached. The cards of both sections discarded were liable to carry records of sickness and lost time under various disease headings and this was particularly so in the case of some of the earlier discharges. The final totals produced are therefore a little lower than the actual sickness absence experience of the Dockyard, but it is nevertheless submitted that they give a reasonably accurate picture of sickness absence in a mixed labour force and that the trends of disease in the various groups discussed are reliably indicated.

\section{Results}

Age Distribution of Employees.-The age distribution is displayed in Table 1 .

It will be seen that while the Chinese and Malays are most represented in the first two age groups, the Indians have their majority in the years 26 to 45 . The Chinese also have the relatively high percentage of 8.8 of their total in the oldest age group, more than twice that of Indians or Malays.

Sickness Absence as Affected by Age.-When sickness absence in the Dockyard as a whole is analysed,

TABLE 2

NUMBERS EMPLOYED IN A MIXED ASIAN LABOUR FORCE IN AGE GROUPS WITH RATES OF SICKNESS ABSENCE, $1955-56$

\begin{tabular}{c|c|c|c|c|c}
\hline $\begin{array}{c}\text { Age } \\
\text { (years) }\end{array}$ & $\begin{array}{c}\text { No. of } \\
\text { Workers }\end{array}$ & $\begin{array}{c}\text { No. of } \\
\text { Spells }\end{array}$ & $\begin{array}{c}\text { Inception } \\
\text { Rate per } \\
1,000 \\
\text { Workers }\end{array}$ & $\begin{array}{c}\text { No. of } \\
\text { Shifts } \\
\text { Lost }\end{array}$ & $\begin{array}{c}\text { Shifts } \\
\text { Lost } \\
\text { per } \\
\text { Worker }\end{array}$ \\
\hline $16-$ & 1,781 & 2,272 & $1,275 \cdot 7$ & 21,288 & $11 \cdot 95$ \\
$26-$ & 2,512 & 3,724 & $1,482 \cdot 5$ & 31,855 & $12 \cdot 68$ \\
$36-$ & 2,205 & 2,525 & $1,145 \cdot 1$ & 26,585 & $12 \cdot 06$ \\
$46-$ & 1,170 & 1,021 & $872 \cdot 6$ & 13,196 & $11 \cdot 28$ \\
$56+$ & 410 & 249 & $607 \cdot 3$ & 4,470 & $10 \cdot 90$ \\
\hline Total & 8,078 & 9,791 & $1,212 \cdot 1$ & 97,394 & $12 \cdot 06$ \\
\hline
\end{tabular}

TABLE 3

SICKNESS ABSENCE INCEPTION RATE PER 1,000 MALE INDUSTRIAL EMPLOYEES

\begin{tabular}{c|r|r|r}
\hline Age (years) & Chinese & \multicolumn{1}{|c|}{ Indian } & Malay \\
\cline { 1 - 2 } $16-$ & $1,046 \cdot 1$ & $1,870 \cdot 6$ & 726.6 \\
$26-$ & $1,442 \cdot 6$ & $1,763 \cdot 0$ & 756.0 \\
$36-$ & $761 \cdot 5$ & $1,394.9$ & $500 \cdot 0$ \\
$46-$ & $686 \cdot 6$ & $1,117 \cdot 6$ & 462.4 \\
$56+$ & $453 \cdot 7$ & $883 \cdot 6$ & $458 \cdot 3$ \\
\hline All ages & $987 \cdot 8$ & $1,530 \cdot 7$ & 647.9 \\
\hline
\end{tabular}

figures are produced that may reasonably be accepted as a tenable standard for a mixed Asian labour force (Table 2).

The mixed labour force under discussion is constituted roughly in a ratio of $3: 2: 1$ for Indian, Chinese, and Malay. Any substantial alteration of these proportions would naturally lead to a change in the sickness absence rates.

This is demonstrated in Table 3 which gives the inception rates for age groups under the three ethnic divisions.

The second age group in two instances has the highest inception rate, though in the Indian the youngest group holds this position. All three ethnic groups have inception rates falling steadily with increasing age, from the age group 26 to 35 .

In two other respects the ethnic patterns of sickness absence show marked differences. Table 4 gives the percentages of inceptions and shifts lost when the sickness absences are separated into short (one to seven shifts), medium (eight to 47 shifts), and extended durations (48 shifts and over).

The percentages of inceptions and shifts lost in the longer periods of absence increase broadly as age advances, but there are generally lower percentages of short-term sickness in the Malay compared with the other ethnic groups.

These results confirm that although in the higher age groups inceptions are fewer and the rate of time lost per man is less, when sickness does occur at these ages it tends to be more serious and recovery takes longer.

The frequency distribution of sickness absence in age and ethnic groups is of considerable interest and is displayed in Table 5 .

The percentage of employees free from sickness increases steadily with advancing age, from the lowest age group in the Malays, and from the 26 to 35 age group with the other two races.

The percentages of those experiencing one inception only do not vary greatly, but there are considerable fluctuations in the levels of those with two to three inceptions, four to six, and those with seven inceptions or more.

The final column of Table 5 which gives the percentages of absence frequency for the ethnic groups 
TABLE 4

PERCENTAGES OF TOTAL INCEPTIONS AND SHIFTS LOST BY MALE INDUSTRIAL WORKERS IN SHORT, MEDIUM, AND EXTENDED PERIODS OF SICKNESS ABSENCE AND IN AGE AND ETHNIC GROUPS

\begin{tabular}{|c|c|c|c|c|c|c|c|c|c|c|c|}
\hline \multirow{3}{*}{$\begin{array}{l}\text { Ethnic } \\
\text { Group }\end{array}$} & \multirow{3}{*}{$\begin{array}{c}\text { Duration } \\
\text { of Sickness } \\
\text { Absence }\end{array}$} & \multicolumn{10}{|c|}{ Age (years) } \\
\hline & & \multicolumn{2}{|c|}{$16-25$} & \multicolumn{2}{|c|}{$26-35$} & \multicolumn{2}{|c|}{$36-45$} & \multicolumn{2}{|c|}{$46-55$} & \multicolumn{2}{|c|}{$56+$} \\
\hline & & Inceptions & $\begin{array}{c}\text { Shifts } \\
\text { Lost }\end{array}$ & Inceptions & $\begin{array}{l}\text { Shifts } \\
\text { Lost }\end{array}$ & Inceptions & $\begin{array}{c}\text { Shifts } \\
\text { Lost }\end{array}$ & Inceptions & $\begin{array}{c}\text { Shifts } \\
\text { Lost }\end{array}$ & Inceptions & $\begin{array}{l}\text { Shifts } \\
\text { Lost }\end{array}$ \\
\hline Chinese & $\begin{array}{l}\text { Short } \\
\text { Medium } \\
\text { Extended }\end{array}$ & $\begin{array}{r}79 \cdot 8 \\
19 \cdot 3 \\
0.9\end{array}$ & $\begin{array}{l}38.4 \\
28 \cdot 0 \\
33.6\end{array}$ & $\begin{array}{r}77 \cdot 4 \\
20 \cdot 9 \\
1 \cdot 7\end{array}$ & $\begin{array}{l}35 \cdot 8 \\
29 \cdot 9 \\
34 \cdot 2\end{array}$ & $\begin{array}{r}72 \cdot 2 \\
24 \cdot 4 \\
3 \cdot 5\end{array}$ & $\begin{array}{l}22 \cdot 9 \\
30 \cdot 2 \\
46 \cdot 9\end{array}$ & $\begin{array}{r}60.9 \\
32.6 \\
6.5\end{array}$ & $\begin{array}{l}15 \cdot 1 \\
30 \cdot 7 \\
54 \cdot 2\end{array}$ & $\begin{array}{r}56 \cdot 1 \\
37 \cdot 8 \\
6 \cdot 1\end{array}$ & $\begin{array}{l}12 \cdot 4 \\
34 \cdot 8 \\
52 \cdot 8\end{array}$ \\
\hline Malay & $\begin{array}{l}\text { Short } \\
\text { Medium } \\
\text { Extended }\end{array}$ & $\begin{array}{r}67 \cdot 2 \\
29 \cdot 6 \\
3 \cdot 1\end{array}$ & $\begin{array}{l}22 \cdot 9 \\
33 \cdot 8 \\
43 \cdot 4\end{array}$ & $\begin{array}{r}71 \cdot 0 \\
27.7 \\
1.3\end{array}$ & $\begin{array}{l}34 \cdot 0 \\
39 \cdot 8 \\
26 \cdot 2\end{array}$ & $\begin{array}{r}59 \cdot 6 \\
36 \cdot 3 \\
4 \cdot 1\end{array}$ & $\begin{array}{l}17 \cdot 9 \\
35 \cdot 6 \\
46 \cdot 5\end{array}$ & $\begin{array}{r}52 \cdot 5 \\
41 \cdot 2 \\
6 \cdot 2\end{array}$ & $\begin{array}{l}13 \cdot 8 \\
43 \cdot 9 \\
42 \cdot 3\end{array}$ & $\begin{array}{r}68.2 \\
31.8 \\
0.0\end{array}$ & $\begin{array}{r}41.0 \\
59.0 \\
0.0\end{array}$ \\
\hline
\end{tabular}

as a whole displays the racial tendencies towards sickness absence very plainly and with particular contradistinction between Indian and Malay.

When the causes of sickness absence are examined it is necessary to do so in diagnostic groups that display those that have the greatest effect on the sickness rates. After an exhaustive classification had been completed, it was considered advisable to reduce this to 10 diagnostic groups for clarity of presentation. These were as follows:

I. Common cold

II. Tuberculosis

III. Other respiratory disease

IV. Disease of the digestive system

V. Rheumatic conditions

VI. Skin conditions

VII. Injuries

VIII. Communicable disease

IX. Other disease

$\mathrm{X}$. Inadequate diagnosis
Of these the first eight groups were straightforward, having shown themselves to be of particular importance by producing high inception rates per 1,000 workers or a massive loss of shifts over the year. The remainder of the original diagnostic groups that had been the cause of occasional but not repeated or large loss were included in Group IX.

Group X (inadequate diagnosis) was frustrating but unfortunately important. Into this group fell all those cases where inadequate certificates were presented, with such diagnoses as fever, ill health, giddiness, debility, headache, or pain; 1,130 certificates of this nature were produced by some 8,100 industrial employees in the year at a cost of 7,159 shifts, which shows the magnitude of the problem. It was noted subsequently that inadequate medical certificates are much less frequent in Britain.

In diagnostic groups the figures of inceptions (spells) gave a less clear picture of the effects of different illnesses than the corresponding rates of

TABLE 5

PERCENTAGE DISTRIBUTION OF FREOUENCY OF INCEPTIONS (SPELLS) AMONG MALE INDUSTRIAL WORKERS IN AGE AND ETHNIC GROUPS

\begin{tabular}{|c|c|c|c|c|c|c|c|}
\hline \multirow{2}{*}{ Ethnic Group } & \multirow{2}{*}{$\begin{array}{c}\text { No. of Absences } \\
\text { (spells) } \\
\text { per Worker }\end{array}$} & \multicolumn{5}{|c|}{ Age (years) } & \multirow{2}{*}{ All Ages } \\
\hline & & $16-25$ & $26-35$ & $36-45$ & $46-55$ & $56+$ & \\
\hline Chinese & $\begin{array}{c}0 \\
1 \\
2-3 \\
4-6 \\
7+\end{array}$ & $\begin{array}{r}50.7 \\
24.8 \\
16.7 \\
7.1 \\
0.8\end{array}$ & $\begin{array}{r}41 \cdot 5 \\
25 \cdot 7 \\
20 \cdot 2 \\
9 \cdot 3 \\
3 \cdot 2\end{array}$ & $\begin{array}{r}60.8 \\
19.9 \\
14.3 \\
4.7 \\
0.2\end{array}$ & $\begin{array}{r}63.7 \\
19.4 \\
13.2 \\
2.9 \\
0.7\end{array}$ & $\begin{array}{r}69.0 \\
21.3 \\
8.8 \\
0.9 \\
-\end{array}$ & $\begin{array}{r}53.9 \\
22.9 \\
15.9 \\
6.1 \\
1.2\end{array}$ \\
\hline Indian & $\begin{array}{c}0 \\
1 \\
2-3 \\
4-6 \\
7+\end{array}$ & $\begin{array}{r}30.8 \\
20.9 \\
30.7 \\
14.6 \\
3.0\end{array}$ & $\begin{array}{r}29.4 \\
26.8 \\
28.0 \\
13.2 \\
2.6\end{array}$ & $\begin{array}{r}38 \cdot 8 \\
27.0 \\
22 \cdot 3 \\
10 \cdot 3 \\
1.7\end{array}$ & $\begin{array}{r}45 \cdot 4 \\
25 \cdot 7 \\
22 \cdot 3 \\
6.0 \\
0.6\end{array}$ & $\begin{array}{r}53.4 \\
27.4 \\
13.7 \\
4.8 \\
0.7\end{array}$ & $\begin{array}{l}36.0 \\
25.9 \\
25 \cdot 1 \\
11 \cdot 2 \\
1.9\end{array}$ \\
\hline Malay & $\begin{array}{c}0 \\
1 \\
2-3 \\
4-6 \\
7+\end{array}$ & $\begin{array}{r}57 \cdot 2 \\
25 \cdot 1 \\
13 \cdot 9 \\
3 \cdot 8 \\
-\end{array}$ & $\begin{array}{r}63 \cdot 2 \\
17 \cdot 7 \\
14 \cdot 3 \\
4.4 \\
0.4\end{array}$ & $\begin{array}{r}68 \cdot 8 \\
20 \cdot 2 \\
9 \cdot 3 \\
1.3 \\
0.3\end{array}$ & $\begin{array}{r}69.4 \\
20.2 \\
9.3 \\
1.2 \\
\end{array}$ & $\begin{array}{c}70.8 \\
14.6 \\
14.6 \\
-\end{array}$ & $\begin{array}{r}63 \cdot 7 \\
20.5 \\
12.5 \\
3.1 \\
0.2\end{array}$ \\
\hline
\end{tabular}


TABLE 6

SHIFTS LOST PER MALE INDUSTRIAL WORKER IN AGE, ETHNIC, AND DIAGNOSTIC GROUPS

\begin{tabular}{|c|c|c|c|c|c|c|c|}
\hline \multirow{2}{*}{ Ethnic Group } & \multirow{2}{*}{ Diagnostic Group } & \multicolumn{5}{|c|}{ Age (years) } & \multirow{2}{*}{ All Ages } \\
\hline & & $16-25$ & $26-35$ & $36-45$ & $46-55$ & $56+$ & \\
\hline \multirow[t]{2}{*}{ Chinese } & $\begin{array}{l}\text { I } \\
\text { II } \\
\text { III } \\
\text { IV } \\
\text { V } \\
\text { VI } \\
\text { VII } \\
\text { VIII } \\
\text { IX } \\
\text { X }\end{array}$ & $\begin{array}{l}1.25 \\
3 \cdot 13 \\
0.84 \\
1.37 \\
0.19 \\
0.53 \\
0.24 \\
0.44 \\
0.82 \\
0.68\end{array}$ & $\begin{array}{l}2.15 \\
2.81 \\
1.42 \\
1.86 \\
0.44 \\
0.74 \\
0.82 \\
0.50 \\
1.54 \\
0.63\end{array}$ & $\begin{array}{l}0.90 \\
3.60 \\
0.94 \\
1.03 \\
0.20 \\
0.89 \\
0.30 \\
0.14 \\
1.36 \\
0.62\end{array}$ & $\begin{array}{l}0.72 \\
3.69 \\
1.79 \\
1.65 \\
0.26 \\
0.47 \\
0.46 \\
0.17 \\
2.05 \\
0.55\end{array}$ & $\begin{array}{l}0.41 \\
3.14 \\
1.31 \\
0.34 \\
0.39 \\
0.31 \\
1.57 \\
0.05 \\
1.18 \\
0.26\end{array}$ & $\begin{array}{l}1.27 \\
3.22 \\
1.21 \\
1.40 \\
0.29 \\
0.62 \\
0.56 \\
0.32 \\
1.34 \\
0.60\end{array}$ \\
\hline & All sickness absence & $9 \cdot 48$ & $12 \cdot 92$ & $10 \cdot 00$ & $11 \cdot 83$ & $8 \cdot 96$ & $10 \cdot 83$ \\
\hline \multirow[t]{2}{*}{ Indian } & $\begin{array}{l}\text { I } \\
\text { II } \\
\text { III } \\
\text { IV } \\
\text { V } \\
\text { VI } \\
\text { VII } \\
\text { VIII } \\
\text { IX } \\
\mathbf{X}\end{array}$ & $\begin{array}{l}2.05 \\
1.66 \\
2.27 \\
2.24 \\
0.78 \\
0.69 \\
1.24 \\
1.89 \\
1.90 \\
1.57\end{array}$ & $\begin{array}{l}1.82 \\
1.20 \\
2.16 \\
2.56 \\
0.70 \\
0.64 \\
1.40 \\
1.29 \\
1.43 \\
1.36\end{array}$ & $\begin{array}{l}1.49 \\
1.58 \\
1.88 \\
1.92 \\
0.71 \\
0.61 \\
1.36 \\
0.49 \\
2.55 \\
1.08\end{array}$ & $\begin{array}{l}1.32 \\
1.56 \\
1.67 \\
1.65 \\
0.44 \\
0.89 \\
1.06 \\
0.34 \\
2.22 \\
0.73\end{array}$ & $\begin{array}{l}0.69 \\
2.96 \\
2.73 \\
0.97 \\
0.47 \\
2.21 \\
1.91 \\
-\overline{3.91} \\
0.35\end{array}$ & $\begin{array}{l}1.63 \\
1.51 \\
2.03 \\
2.10 \\
0.67 \\
0.73 \\
1.33 \\
0.93 \\
2.08 \\
1.17\end{array}$ \\
\hline & All sickness absence & $16 \cdot 29$ & $14 \cdot 57$ & $13 \cdot 65$ & $11 \cdot 87$ & $16 \cdot 18$ & $14 \cdot 19$ \\
\hline \multirow[t]{2}{*}{ Malay } & $\begin{array}{l}\text { I } \\
\text { II } \\
\text { III } \\
\text { IV } \\
\text { V } \\
\text { VI } \\
\text { VII } \\
\text { VIII } \\
\text { IX } \\
\text { X }\end{array}$ & $\begin{array}{l}1.40 \\
2.96 \\
0.50 \\
0.48 \\
0.29 \\
0.48 \\
1.22 \\
0.56 \\
0.85 \\
0.70\end{array}$ & $\begin{array}{l}1.24 \\
1.37 \\
0.68 \\
0.98 \\
0.34 \\
0.31 \\
0.65 \\
0.23 \\
0.82 \\
0.51\end{array}$ & $\begin{array}{l}0.68 \\
0.71 \\
0.52 \\
0.76 \\
0.14 \\
0.67 \\
2.38 \\
0.19 \\
0.81 \\
0.45\end{array}$ & $\begin{array}{l}0.66 \\
2.38 \\
1.46 \\
0.90 \\
0.35 \\
0.24 \\
0.31 \\
0.19 \\
1.03 \\
0.42\end{array}$ & $\begin{array}{l}0.85 \\
\overline{0.42} \\
1.49 \\
= \\
- \\
\overline{0.84} \\
-\end{array}$ & $\begin{array}{l}1.08 \\
1.76 \\
0.68 \\
0.80 \\
0.28 \\
0.42 \\
1.11 \\
0.30 \\
0.85 \\
0.52\end{array}$ \\
\hline & All sickness absence & $9 \cdot 45$ & $7 \cdot 11$ & $7 \cdot 33$ & 7.97 & 3.60 & $7 \cdot 80$ \\
\hline
\end{tabular}

shifts lost per worker. The latter are tabulated in Table 6 according to age and ethnic groups.

There is a general tendency for time lost to lessen as age increases, but the pattern of many groups is irregular. In some instances in Table 6 the rates are given undue prominence by one or two very extended cases: thus the Chinese age group 46 to 55 in diagnostic Group IX is biased by one case of psychosis lasting 439 shifts; diagnostic Group II in Malay age groups 16 to 25 and 46 to 55 is unbalanced by three long-term cases in the first of these age groups and two in the second. When subdivided in this way the numbers of cases are small and the results should be interpreted with caution.

Certain points in Table 6 are singled out for mention:

(a) The high rates for tuberculosis (Group II) in Chinese compared with Indians or Malays.

(b) The high rates for other respiratory disease (Group III) and digestive conditions (Group IV) for all age groups of Indians.

(c) The high rate of skin conditions (Group VI) in the oldest Indian group.

(d) In general the Malay rates are lower throughout than those of the other two ethnic divisions. (e) The Indian rates as a whole are nearly double those of the Malay group. The youngest Indian age group lost over one and a half shifts per worker in the year from inadequately certificated conditions (Group X).

\section{Discussion}

Before the differences in sickness absence rates between the ethnic divisions which have been shown above can be accepted as inherent, it is necessary to consider some other factors that might be partially responsible. The most obvious are the type of employment, the place of residence, and the diet.

Type of Employment.-An examination of the Dockyard industrial population showed a generally even distribution of ethnic groups but the 10 departments fell naturally into two groups:

(a) Those working in large factory spaces, workshops, and warehouses, and those engaged in construction, repair, and storage.

(b) The small departments working mostly in the open and less exposed to industrial hazard.

The first group included approximately $82 \%$ of all industrial workers and showed inception rates per 
1,000 ranging from 1,259 to 1,568 , shifts lost per worker from 11.2 to $14 \cdot 15$, and no department in this group had more than $48 \%$ of workers without sickness absence during the year.

The second group had inception rates well below 1,000 , lost about seven shifts per worker, and no department had less than $51 \%$ of workers free from sickness absence.

Closer examination of the first group revealed that $91.6 \%$ of the Chinese, $82.1 \%$ of the Indians, and $66.6 \%$ of the Malays worked in the departments concerned.

If ethnic distribution in the technical departments had been even, it would appear likely that the sickness absence rates for the Chinese should be lessened and for the Malays increased: but the Indians who provided approximately their proper quota had high sickness absence rates.

It was also found that while the ethnic distribution in the supervisory grade did not vary much, the distribution for the grades of skilled artisan, semiskilled, and labourers were respectively $60.5,22 \cdot 3$, and $7.0 \%$ for Chinese, $49.7,17.0$, and $23.9 \%$ for Indians, and $37 \cdot 7,31.9$, and $19.5 \%$ for Malays. Thus the Chinese tended towards skilled trades while the Indians actually provided 1,008 of the 1,454 labourers employed. The Malays were more evenly distributed.

These four grades, i.e. supervisory, skilled artisans, semi-skilled, and labourers produced inception rates per 1,000 workers of $1,098,1,356,976$, and 1,146 respectively, while the shifts lost per worker were $11.05,13 \cdot 17,10.87$, and 10.86 respectively. The skilled artisans had sickness absence rates higher than those of the other grades and associated with the relatively high proportion of Chinese in this grade. These facts lend themselves to a Chinese rate higher than might otherwise have been expected.

Place of Residence.-Investigation of one large department regarding the relation of sickness absence to place of residence showed that the Chinese were most affected with regard to short-term cases (one to seven shifts) both in inception rate and shifts lost. Both rates rose steadily the further from the base the men resided, from a lower limit of 582 inceptions per 1,000 (short term only) and $2 \cdot 21$ shifts lost per man, to 1,498 inceptions per 1,000 and $6 \cdot 32$ shifts lost by those residing in Singapore City. The same effect was noted with the Malays, but to a lesser extent, the corresponding rates rising from 630 and 2.93, to 944 and 3.44. Surprisingly, the Indian rates remained approximately at the same level.

It is difficult not to correlate this rise with the increased ease with which medical certificates could be obtained in the city. Again the Chinese, with
$30 \%$ living in Singapore City, compared with $3 \%$ of Indians and $12 \%$ of Malays, were the most affected.

Nutrition and Diet.-During the survey few actual cases of malnutrition were found, but vitamin deficiencies appeared as vague paraesthesiae in the limbs, sometimes with sensory changes resembling peripheral neuritis; also as recurrent refractory styes and slow healing wounds responsive to vitamin therapy. These signs and even more the low levels of haemoglobin found in antenatal tests suggested that a considerable amount of subclinical malnutrition existed in the population of the naval base and was especially marked in the Indian community.

Investigations undertaken into the average weekly diets of the main ethnic groups showed that the Malay menu was adequate in all respects while both the Chinese and Indian were not. In the latter the quantities of chicken, meat, potatoes, and green vegetable, were all too small while the Chinese were short of all types of vegetable, sugar, and fish, though the fish soup made from the bones probably made up for this to some extent. Analysis of the Indian diet showed it to be inadequate as regards calorie value, protein, calcium, vitamin $\mathrm{A}$, and riboflavin. The Chinese diet was deficient in the last three items only.

Not only were the foodstuffs themselves inadequate, but the method of cooking used by Indians is known to waste more of the value conserved by the other two races, especially with regard to calcium, iron, total phosphorus, and phytic acid phosphorus.

To summarize these findings, it appears that if correction of sickness absence rates could be made for the chosen form of occupation, the grade of employment, and the place of residence, the Chinese might produce figures closer to those of Malays. The Indians, however, would remain largely unaffected by any such correction and would continue to produce rates approximately twice those of Malays. Finally, there seems to be no explanation for the marked susceptibility to tuberculosis among the Chinese.

Comparable Statistics.-Few similar investigations have been carried out in Malaya, but by the courtesy of the Singapore Harbour Board certain figures comparable with those of the present survey were obtained.

In the Harbour Board time lost was recorded in days. In Table 7 shifts lost in H.M. Dockyard are converted to days lost by multiplying by $6 / 11$.

The marked difference in sickness absence rates between the two organizations can be explained to some extent by local circumstances. The degree of 
TABLE 7

COMPARISON OF INCEPTION RATES AND DAYS LOST FROM SICKNESS ABSENCE BY MALE INDUSTRIAL WORKERS OF THE SINGAPORE HARBOUR BOARD AND H.M. DOCKYARD, SINGAPORE AND IN THE ETHNIC GROUPS, 1955-56

\begin{tabular}{|c|c|c|c|c|c|c|c|c|c|}
\hline \multirow{3}{*}{ Organization } & \multicolumn{7}{|c|}{ Ethnic Group } & \multirow{2}{*}{\multicolumn{2}{|c|}{$\begin{array}{l}\text { All Industrial } \\
\text { Workers }\end{array}$}} \\
\hline & \multirow{2}{*}{$\begin{array}{l}\text { No. at } \\
\text { Risk }\end{array}$} & \multicolumn{2}{|c|}{ Chinese } & \multicolumn{2}{|c|}{ Indians } & \multicolumn{2}{|c|}{ Malays } & & \\
\hline & & $\begin{array}{l}\text { Inceptions } \\
\text { per } 1,000 \\
\text { Workers }\end{array}$ & $\begin{array}{l}\text { Days Lost } \\
\text { per } \\
\text { Worker }\end{array}$ & $\begin{array}{l}\text { Inceptions } \\
\text { per } 1,000 \\
\text { Workers }\end{array}$ & $\begin{array}{c}\text { Days Lost } \\
\text { per } \\
\text { Worker }\end{array}$ & $\begin{array}{l}\text { Inceptions } \\
\text { per 1,000 } \\
\text { Workers }\end{array}$ & $\begin{array}{l}\text { Days Lost } \\
\text { per } \\
\text { Worker }\end{array}$ & $\begin{array}{l}\text { Inceptions } \\
\text { per } 1,000 \\
\text { Workers }\end{array}$ & $\begin{array}{c}\text { Days Lost } \\
\text { per } \\
\text { Worker }\end{array}$ \\
\hline $\begin{array}{l}\text { Singapore Harbour } \\
\text { Board } \\
\text { H.M. Dockyard }\end{array}$ & $\begin{array}{l}5,224 \\
8,090\end{array}$ & $\begin{array}{l}756.4 \\
987.8\end{array}$ & $\overline{5 \cdot 90}$ & $\begin{array}{r}861 \cdot 9 \\
1,530 \cdot 7\end{array}$ & $\overline{7 \cdot 73}$ & $\begin{array}{l}733.9 \\
647.9\end{array}$ & $\overline{4 \cdot 25}$ & $\begin{array}{r}798 \cdot 2 \\
1,212 \cdot 7\end{array}$ & $\begin{array}{l}1.88 \\
6.58\end{array}$ \\
\hline
\end{tabular}

medical control exercised by the Board is enhanced by a requirement that no medical certificate can be accepted without countersignature by the Board's own physician. Many of the doubtfully certificated short-term illnesses included in the Dockyard figures could not therefore arise with Harbour Board employees. Long-term sicknesses treated in Dockyard employees are not accepted by the Harbour Board for such extended periods, which partially accounts for the difference in rates between the two organizations.

In turning to Europe for further comparisons 13.4 days lost per worker in a year have been quoted; Forssman (1954) gave an inception rate per 1,000 workers of $1,390.8$ and 12.66 days lost; Buzzard and Shaw (1952) gave 687 and 14.1; Sutherland and Whitwell (1948) gave 448.5 and 9.44 respectively. All these were industrial workers, mostly in the United Kingdom.

The most recent and detailed figures were published by the London Transport Executive (Norman and Spratling, 1956). They are given for different occupations and shown in age groups both for total sickness absence and for certain diagnostic groups; all these can be compared with similar records of the Dockyard survey and give a generally parallel picture. That the London Transport age groups were of five years instead of 10 and differ slightly in their components cannot disguise the general trends.
The period covered in the London Transport survey ranged from one to 182 days only; any periods exceeding this were not included in the records. This is not very different from the scope of the Dockyard records. In certain circumstances payment for sickness covering 130 working days, which did not include Sundays or the numerous festivals, was allowed in the Dockyard.

Table 8 has been prepared from the London Transport figures (Norman and Spratling, 1956) for comparison with Tables 3 and 7 above.

Inception rates at all ages vary from 620 to 1,026 compared with the Asian range of 648 to 1,531 , but there is really no great difference between the London, Chinese, or Malay rates. On the other hand all Asian inception rates tended to fall steadily with increasing age, while in London the rates fell in each case until the 35 to 44 age group was reached, when they increased. The rates may have been affected by differential wastage.

Days lost per employee per annum in London Transport were more than in Singapore, but the age distributions of the respective populations were different. Even the Indian, with relatively high loss of time in Singapore, did not lose as many days as the lowest "all ages" group in London Transport. In London the 25 to 34 age group displayed the lowest rates, which was not the case in Singapore; and the considerable rise in days lost in London in the

TABLE 8

INCEPTION RATES AND DAYS LOST FROM SICKNESS IN INDUSTRIAL MALE EMPLOYEES OF THE LONDON TRANSPORT EXECUTIVE, 1949-52

\begin{tabular}{|c|c|c|c|c|c|c|c|c|c|c|c|c|}
\hline \multirow[b]{3}{*}{$\underset{\text { (years) }}{\text { Age }}$} & \multicolumn{12}{|c|}{ Industrial Groups } \\
\hline & \multicolumn{3}{|c|}{ Central Bus Drivers } & \multicolumn{3}{|c|}{ Central Bus Male Conductors } & \multicolumn{3}{|c|}{ Motormen and Guards } & \multicolumn{3}{|c|}{ Male Workshop Staff } \\
\hline & $\begin{array}{l}\text { No. of } \\
\text { Man } \\
\text { Years }\end{array}$ & \begin{tabular}{|c|} 
Inception \\
Rate per \\
1,000 Em- \\
ployees \\
per \\
Annum
\end{tabular} & \begin{tabular}{|c|} 
Days \\
Lost per \\
Employee \\
per \\
Annum
\end{tabular} & $\begin{array}{l}\text { No. of } \\
\text { Man } \\
\text { Years }\end{array}$ & \begin{tabular}{|c|} 
Inception \\
Rate per \\
1,000 Em- \\
ployees \\
per \\
Annum
\end{tabular} & $\begin{array}{c}\text { Days } \\
\text { Lost per } \\
\text { Employee } \\
\text { per } \\
\text { Annum }\end{array}$ & $\begin{array}{l}\text { No. of } \\
\text { Man } \\
\text { Years }\end{array}$ & \begin{tabular}{|c|} 
Inception \\
Rate per \\
1,000 Em- \\
ployees \\
per \\
Annum \\
\end{tabular} & $\begin{array}{c}\text { Days } \\
\text { Lost per } \\
\text { Employee } \\
\text { per } \\
\text { Annum } \\
\end{array}$ & $\begin{array}{l}\text { No. of } \\
\text { Man } \\
\text { Years }\end{array}$ & $\begin{array}{c}\text { Inception } \\
\text { Rate per } \\
1,000 \text { Em- } \\
\text { ployees } \\
\text { per } \\
\text { Annum }\end{array}$ & $\begin{array}{c}\text { Days } \\
\text { Lost per } \\
\text { Employee } \\
\text { per } \\
\text { Annum }\end{array}$ \\
\hline $\begin{array}{l}\text { Up to } 24 \\
25- \\
35- \\
45- \\
55+\end{array}$ & $\begin{array}{r}24 \\
11,391 \\
15,762 \\
17,244 \\
12,078\end{array}$ & \begin{tabular}{|l|}
$667 \cdot 7$ \\
$770 \cdot 8$ \\
$644 \cdot 3$ \\
$730 \cdot 4$ \\
$842 \cdot 9$ \\
\end{tabular} & \begin{tabular}{|r|}
2.79 \\
5.29 \\
6.27 \\
11.39 \\
17.66 \\
\end{tabular} & $\begin{array}{r}4,132 \\
15,686 \\
14,179 \\
7,838 \\
6,343\end{array}$ & \begin{tabular}{|r|}
$1,747 \cdot 3$ \\
$1,088 \cdot 9$ \\
$739 \cdot 4$ \\
$926 \cdot 0$ \\
$1,163 \cdot 5$ \\
\end{tabular} & \begin{tabular}{|r|}
$7 \cdot 69$ \\
$6 \cdot 59$ \\
$6 \cdot 78$ \\
$12 \cdot 70$ \\
$22 \cdot 10$ \\
\end{tabular} & $\begin{array}{r}588 \\
2,379 \\
3,033 \\
2,967 \\
1,931\end{array}$ & $\begin{array}{r}1,113.9 \\
702.8 \\
545.7 \\
551.7 \\
590.4 \\
\end{array}$ & \begin{tabular}{|r|}
5.65 \\
4.98 \\
6.18 \\
9.15 \\
15.02 \\
\end{tabular} & $\begin{array}{l}1,136 \\
3,096 \\
3,938 \\
4,351 \\
3,449\end{array}$ & $\begin{array}{r}985.0 \\
750.0 \\
645.5 \\
761.9 \\
1,018 \cdot 8\end{array}$ & $\begin{array}{r}7 \cdot 27 \\
5 \cdot 67 \\
6 \cdot 13 \\
10 \cdot 32 \\
14.94 \\
\end{array}$ \\
\hline All ages & 56,499 & $738 \cdot 6$ & $10 \cdot 07$ & 48,178 & $1,025 \cdot 8$ & $9 \cdot 77$ & 10,898 & $620 \cdot 2$ & $8 \cdot 26$ & 15,970 & $802 \cdot 2$ & $9 \cdot 17$ \\
\hline
\end{tabular}


TABLE 9

DAYS LOST PER EMPLOYEE PER ANNUM IN CERTAIN DIAGNOSTIC GROUPS AMONG THREE ETHNIC GROUPS IN SINGAPORE AND FOUR INDUSTRIAL DIVISIONS IN LONDON TRANSPORT (Norman and Spratling, 1956)

\begin{tabular}{|c|c|c|c|c|c|c|c|}
\hline \multirow[b]{2}{*}{ Diagnostic Group } & \multicolumn{3}{|c|}{$\begin{array}{c}\text { Singapore Dockyard Ethnic Groups } \\
1955-56\end{array}$} & \multicolumn{4}{|c|}{$\begin{array}{c}\text { London Transport Industrial Divisions } \\
1949-52\end{array}$} \\
\hline & Chinese & Indian & Malay & $\begin{array}{c}\text { Central } \\
\text { Bus } \\
\text { Drivers }\end{array}$ & $\begin{array}{c}\text { Central } \\
\text { Bus Male } \\
\text { Conductors }\end{array}$ & $\begin{array}{l}\text { Motormen } \\
\text { and } \\
\text { Guards }\end{array}$ & $\begin{array}{c}\text { Male } \\
\text { Workshop } \\
\text { Staff }\end{array}$ \\
\hline $\begin{array}{ll}\text { I. } & \text { Common cold } \\
\text { II. Tuberculosis } \\
\text { III. Other respiratory disease } \\
\text { IV. } \\
\text { V. Sknditions of digestive system } \\
\text { VI. Injuries }\end{array}$ & $\begin{array}{l}0.69 \\
1.76 \\
0.66 \\
0.76 \\
0.34 \\
0.30\end{array}$ & $\begin{array}{l}0.89 \\
0.82 \\
1.11 \\
1 \cdot 15 \\
0.40 \\
0.73\end{array}$ & $\begin{array}{l}0.59 \\
0.96 \\
0.37 \\
0.44 \\
0.23 \\
0.61\end{array}$ & $\begin{array}{l}1 \cdot 13 \\
0.11 \\
1.65 \\
1.80 \\
0.53 \\
0.91\end{array}$ & $\begin{array}{l}1.18 \\
0.14 \\
1.58 \\
1.67 \\
0.54 \\
1.01\end{array}$ & $\begin{array}{l}0.75 \\
0.10 \\
1.60 \\
1.61 \\
0.36 \\
0.67\end{array}$ & $\begin{array}{l}1.09 \\
0.15 \\
1.46 \\
1.45 \\
0.55 \\
0.66\end{array}$ \\
\hline
\end{tabular}

two oldest age groups had no counterpart in the Singapore Dockyard. Differing social and employment conditions may have contributed to these observed differences.

From among the diagnostic group tables a certain number can be extracted to provide a comparison with six of the 10 groups used in the Dockyard survey. These are shown in Table 9.

The London Transport data quoted relate only to spells of four to 182 days duration, while the figures from Singapore are for all certified sickness absence. Of the three respiratory groups, only tuberculosis is completely out of proportion, with a particularly high rate in the Chinese. In the two other respiratory groups the London workers experienced considerably more absence, and digestive system conditions followed the same pattern. The differences in the remaining conditions (Table 9) were not as marked.

The short spells of sickness absence excluded from the London Transport statistics provided 28.9, 33.9 , and $26.6 \%$ respectively of the time lost by Chinese, Indian, and Malay, an overall $31.4 \%$. In the United Kingdom, national insurance sickness benefit is withheld for the first three days of sickness, and it is unlikely that the proportion of time lost due to short-term illness would be as great as that in the Singapore Dockyard. It is reasonable to assume that to cover all sickness absence, the figures given for the industrial divisions in London Transport should be increased, possibly to add about a third to the totals given in Table 9.

The findings of the analyses of sickness absence among Chinese, Indian, and Malay workers in H.M. Dockyard, Singapore and the comparisons with equivalent rates for industrial workers in Europe demonstrate that sickness absence in South East Asia is fundamentally affected by race, age, and occupation, and that it differs materially from that of similar age or occupation groups in Britain. It is evident that the ethnic grouping of the population concerned must be taken into consideration in studies of sickness absence.

I am indebted to Surgeon Vice-Admiral W. R. S. Panckridge, C.B., Medical Director-General of the Navy, for permission to publish this article.

\section{REFERENCES}

Buzzard, R. B., and Shaw, W. J. (1952). Brit. J. industr. Med., 9, 282. Forssman, S. (1954). XI Congresso Internationale di Medicina del Lavoro.

Norman, L. G., and Spratling, F. H. (1956.) Health in Industry: A Contribution to the Study of Sickness Absence. (London TranSport Executive.) Butterworth, London.

Singapore Harbour Board (1955). Personal communication. Sutherland, I., and Whitwell, G. P. B. (1948). Brit. J. industr. Med.,
5, 77. 